\title{
High doses of lidocaine as a constant rate infusion in propofol/ fentanyl anaesthetized sheep: cardiorespiratory effects
}

\section{Infusão contínua de altas doses de lidocaína em ovinos anestesiados com propofol/fentanil: efeitos cardiorrespiratórios}

\author{
Ewaldo de Mattos-Junior ${ }^{1 *}$; Antonio Humberto Hamad Minervino'; \\ Raimundo Alves Barrêto-Júnior ${ }^{3}$; Frederico Augusto Mazzocca Lopes Rodrigues ${ }^{4}$; \\ Carolina Akiko Sato Cabral Araújo ${ }^{4}$; Enrico Lippi Ortolani ${ }^{5}$; \\ Silvia Renata Gaido Cortopassi ${ }^{6}$
}

\begin{abstract}
The aim of this study was to investigate the cardiorespiratory and anesthetic-sparing effects of a highdose CRI of lidocaine $(200 \mu \mathrm{g} / \mathrm{kg} / \mathrm{min})$ administered with a propofol $/$ fentanyl regimen to sheep. Twelve adult, castrated male sheep $(\mathrm{BW}=32.1 \pm 4.9 \mathrm{~kg}$ ), were used in a prospective, randomized clinical trial. All animals were premedicated with xylazine $(0.05 \mathrm{mg} / \mathrm{kg}$, i.m. $)$. Animals in the GPF group were induced with propofol $(3 \mathrm{mg} / \mathrm{kg})$ and fentanyl $(2.5 \mu \mathrm{g} / \mathrm{kg})$ intravenously, and anesthesia was maintained with a CRI of propofol (500 $\mu \mathrm{g} / \mathrm{kg} / \mathrm{min})$ and fentanyl $(0.15 \mu \mathrm{g} / \mathrm{kg} / \mathrm{min})$. In the GPFL group, animals were induced with propofol $(3 \mathrm{mg} / \mathrm{kg})$, fentanyl $(2.5 \mu \mathrm{g} / \mathrm{kg})$ and lidocaine $(2.5 \mathrm{mg} / \mathrm{kg})$ intravenously, and anesthesia was maintained with a CRI of propofol $(500 \mu \mathrm{g} / \mathrm{kg} / \mathrm{min})$, fentanyl $(0.15 \mu \mathrm{g} / \mathrm{kg} / \mathrm{min})$ and lidocaine $(200 \mu \mathrm{g} / \mathrm{kg} / \mathrm{min})$; after ten minutes of anesthesia, the propofol dose was reduced by $25 \%$ (from $500 \mu \mathrm{g} / \mathrm{kg} / \mathrm{min}$ to $375 \mu \mathrm{g} / \mathrm{kg} / \mathrm{min}$ ). Cardiorespiratory parameters were recorded from 15 minutes after preanesthetic medication administration (T0) to the end of the anesthetic procedure (T7). The time points were as follows: T0 - 15 minutes after preanesthetic medication administration; $\mathrm{T} 1$ - after anesthesia induction and orotracheal intubation; T2 - 15 minutes of anesthesia; T3 - during traction on the liver; T4 - during bowel clamping; T5 - during muscle suture; T6 - at the end of skin suture; and T7 - 15 minutes after the end of anesthesia. Apnea was present in all animals during anesthesia induction and required mechanical ventilation. There was no statistical difference in HR and MAP between any time points compared to the baseline value $(p>0.05)$; MAP was lower in the GPF group $(p<0.05)$ at time T6. In conclusion, this dose of lidocaine was sufficient to reduce the propofol requirement by $25 \%$. A high-dose CRI of lidocaine in combination with a propofol/fentanyl regmine did not promote significant cardiovascular changes and was effective in reducing the propofol dose by $25 \%$.
\end{abstract}

Key words: Sheep, local anesthetic, injectable anesthetic, opioids

${ }^{1}$ Prof. Dr. de Anestesiologia e Farmacologia Veterinária, Universidade de Franca, Franca, SP. E-mail: ewaldomattos@hotmail.com

${ }^{2}$ Prof. Dr. Instituto de Biodiversidade e Floresta, Universidade Federal do Oeste do Pará, Santarém, PA. E-mail: hhamad@usp.br

${ }^{3}$ Prof. Dr. de Clínica Médica de Ruminantes, Universidade Federal do Semi-Árido, Mossoró, RN. E-mail: barreto@ufersa.br

${ }^{4}$ Discente(s) do Programa de Pós-Graduação em Clínica Veterinária, Faculdade de Medicina Veterinária e Zootecnia, Universidade de São Paulo, FMVZ/USP, São Paulo, SP. E-mail: fmazzocca@usp.br; carolcabral@usp.br

${ }^{5}$ Prof. Titular do Dept $^{\circ}$ de Clínica Médica, F FMVZ/USP, São Paulo, SP. E-mail: enrico.ortolani@pq.cnpq.br

${ }^{6}$ Prof $^{a}$. Livre-docente do Dept ${ }^{\circ}$ de Cirurgia, FMVZ/USP, São Paulo, SP. E-mail: silcorto@usp.br

* Author for correspondence 


\section{Resumo}

O objetivo desse estudo foi investigar os efeitos cardiorrespiratórios e a redução na dose de propofol, mediante a infusão contínua de altas doses de lidocaína $(200 \mu \mathrm{g} / \mathrm{kg} / \mathrm{min})$ em associação ao propofol/ fentanil. Para tanto, foram utilizados 12 ovinos machos castrados (peso médio de 32,1 $\pm 4,9 \mathrm{~kg}$ ), distribuídos em dois grupos de seis animais, designados como grupo GPF e GPFL em estudo clínico, prospectivo e aleatório. Todos os animais foram pré-medicados com xilazina $(0,05 \mathrm{mg} / \mathrm{kg}$, i.m.). A indução anestésica do grupo GPF constou de propofol $(3 \mathrm{mg} / \mathrm{kg})$ e fentanil $(2,5 \mu \mathrm{g} / \mathrm{kg})$ adminitrados por via intravenosa e a anestesia foi mantida com a infusão contínua de propofol $(500 \mu \mathrm{g} / \mathrm{kg} / \mathrm{min})$ e fentanil $(0,15 \mu \mathrm{g} / \mathrm{kg} / \mathrm{min})$. No grupo GPFL foram induzidos a anestesia com propofol $(3 \mathrm{mg} / \mathrm{kg})$, fentanil $(2,5 \mu \mathrm{g} / \mathrm{kg})$ e lidocaína $(2,5 \mathrm{mg} / \mathrm{kg})$, i.v.; após 10 minutos de manutenção anestésica, neste grupo a dose de propofol foi reduzida em $25 \%(500 \mu \mathrm{g} / \mathrm{kg} / \mathrm{min}$ para $375 \mu \mathrm{g} / \mathrm{kg} / \mathrm{min})$. Os parâmetros cardiorrespiratórios foram coletados 15 minutos após a medicação pré-anestésica (T0) até o término do procedimento cirúrgico (T7). Os tempos correspondentes foram: T0 - 15 minutos após a administração da medicação pré-anestésica; T1 - imediatamente após a indução anestésica e entubação orotraqueal; T2 - 15 minutos de anestesia; T3 - durante a tração do fígado; T4 - durante o pinçamento do intestino; T5 - sutura da musculatura; T6 - final da sutura de pele e T7 - 15 minutos do término da anestesia. Em todos os animais foi observado apnéia após a indução necessitando de ventilação mecânica. Em relação a frequência cardíaca e pressão arterial média, não houve diferença estatística em nenhum dos grupos comparativamente ao valor basal ( $\mathrm{p}>0,05)$; os valores médios da pressão arterial foram superiores no grupo GPF no momento T6 $(\mathrm{p}<0,05)$. A infusão contínua de altas doses de lidocaína em associação ao propofol/fentanil foi suficiente para reduzir a dose do propofol em $25 \%$, sem alterar de maneira significativa os parâmetros cardiorrespiratórios.

Palavras-chave: Ovinos, anestésico local, anestesia intravenosa, opioides

\section{Introduction}

Currently, there are several anesthetic procedures recommended for small ruminants, i.e., sheep and goats. Regardless of whether the anesthetic protocol involves inhalation and/or venous anesthesia, overall safety and rapid recovery are crucial.

Propofol is an intravenous ultra-short acting general anesthetic, with rapid elimination and few side effects. It is widely used for the induction and maintenance of intravenous general anesthesia in humans and has been evaluated in dogs (NOLAN; REID, 1993), cats (BREARLEY; KELLAGHER; HALL, 1988), horses (NOLAN; HALL, 1985) and sheep (CORREIA; NOLAN; REID, 1996). Additionally, it has a powerful hypnotic action but weak analgesic actions; hence, it requires the addition of analgesic drugs when used for anesthetic maintenance (BRANSON, 2007). Propofol administered to sheep, whether alone or in combination with ketamine, resulted in stable cardiovascular (heart rate, blood pressure) and respiratory parameters throughout anesthesia (CORREIA; NOLAN; REID, 1996).

Fentanyl is a short-acting, synthetic opioid with potent analgesic action. When given intravenously, its peak concentration occurs within 5 minutes, and its duration of action is approximately 30 minutes. Its most common side effects include bradycardia (when administered by rapid intravenous infusion) and respiratory depression. Due to these characteristics, it is commonly used as a continuous infusion in combination with the anesthetic protocol (LAMONT; MATTHEWS, 2007). The efficiency of fentanyl on nociceptive thermal and mechanical stimulation and the respiratory depression when given as a bolus in doses ranging from 5 to 20 $\mu \mathrm{g} / \mathrm{kg}$ have been evaluated (WATERMAN; LIVINGSTON; AMIN, 1990). The higher doses were required to achieve analgesia; however, at a $10 \mu \mathrm{g} / \mathrm{kg}$ dose, there was a decrease in $\mathrm{PaO}_{2}$ and an increase in $\mathrm{PaCO}_{2}$ at 5 and 10 minutes after administration, with the values returning to baseline within 15 minutes. 
Lidocaine when administered intravenously is effective in reducing the minimum alveolar concentration of isoflurane and sevoflurane in dogs (VALVERDE et al., 2004, MATSUBARA et al., 2009) and cats (PYPENDOP; ILKIW, 2005). The intravenous administration of lidocaine halved the necessary dose of thiopental required to induce anesthesia in dogs, with less respiratory depression and increased cardiovascular stability (RAWLINGS; KOLATA, 1983). In goats, lidocaine given as a constant rate infusion (CRI) of $100 \mu \mathrm{g} / \mathrm{kg} /$ min decreased the minimum alveolar concentration of isoflurane by $18.7 \%$ (DOHERTY et al., 2007). In horses, the isoflurane requirement was reduced by $61 \%$ when lidocaine was administered at $100 \mu \mathrm{g} / \mathrm{kg} / \mathrm{min}$ along with ketamine $(50 \mu \mathrm{g} / \mathrm{kg} /$ min) (ENDERLE et al., 2008). Mannarino (2002) observed that the inclusion of $250 \mu \mathrm{g} / \mathrm{kg} /$ minute of lidocaine in the protocol with propofol reduced the dose of the propofol needed by $21 \%$ whithout hemodynamic changes.

Although several drugs can be used for intravenous general anesthesia, none of them has the necessary properties to be given alone; therefore, evaluation of combinations of drugs is necessary for adequate anesthesia. The objective of the study was to determine the cardiorespiratory effects of high-dose lidocaine given as a CRI in combination with a propofol/fentanyl regimen in sheep subjected to laparotomy for liver and intestinal biopsy. The reduction of the propofol dose by $25 \%$ in conjunction with a lidocaine CRI was evaluated.

\section{Matherial and Methods}

The Animal Care and Use Committee of the Faculdade de Medicina Veterinária e Zootecnia da Universidade de São Paulo, approved the study, registered as protocol number 2178/2008, and the procedures followed the ethical principles of animal experimentation.

\section{Animals}

Twelve adult, female sheep (ages 2 to 5 years) with a mean weight of $32.1 \pm 4.9 \mathrm{~kg}$ were used in the study. The animals were maintained in holding pens, 6 animals per pen, and received grass hay and ad libitum water. They were acclimated for 20 days prior to the beginning of the experiment. Clinical evaluations (including physical examination, complete hematological and biochemical profiles and complete coproparasitologic examination) were performed to ensure that all animals were healthy.

\section{Instrumentation and Monitoring}

The animals were held with mininum restraints in the standing position immediately after premedication for instrumentation. The heart rate (HR), recorded as beats per minute (bpm), and cardiac rhythm were assessed by means of hemodynamic monitoring electrocardiograph electrodes (Dash 3000 - General Electric, Helsinki, FI). Electrodes were fixed to the shaved skin of the animals with adhesive tape. The mean arterial blood pressures (MAP) were measured using a catheter inserted into the middle ear artery and connected to the pressure transducer of the hemodynamic monitor (the zero reference point was set at the level of the sternum). The rectal temperature $\left({ }^{\circ} \mathrm{C}\right)$ was obtained using a clinical thermometer inserted in the animal's rectum. The respiratory rate data were collected by counting the thoracic movements for 1 minute $\left(f_{R}\right)$ and were recorded as respiratory movements per minute (rmm). The end-tidal carbon dioxide $\left(\mathrm{ETCO}_{2}\right)$ was measured using a mainstream type sensor connected between the endotracheal tube and the swivel valve of the respirator. The arterial oxygen saturation $\left(\mathrm{SpO}_{2}\right)$, given in $\%$, was measured by a pulse oximeter (Dash 3000 - General Electric, Helsinki, Finland) with the sensor placed on the labial mucosa. Arterial blood samples were collected to obtain the arterial $\mathrm{pH}$; partial pressure of carbon dioxide $\left(\mathrm{PaCO}_{2}\right)$, in $\mathrm{mmHg}$; partial pressure of oxygen $\left(\mathrm{PaO}_{2}\right)$, in $\mathrm{mmHg}$; bicarbonate 
ion $\left(\mathrm{HCO}_{3}^{-}\right)$, in $\mathrm{mmol} / \mathrm{L}$; and base deficits or excess $(\mathrm{DB} / \mathrm{EAB})$, in $\mathrm{mmol} / \mathrm{L}$. The arterial blood collection was performed by the catheter allocated to the auricular artery. Each sample was collected as $1 \mathrm{ml}$ of blood volume in a disposable syringe containing heparin. After collection, the needle was sealed with a rubber lid to avoid contact with air, and analysis using a $\mathrm{pH}$ and blood gas analyzer was immediately performed (ABL 5 blood gas analyzer, Radiometer, Copenhagen, Denmark). The recovery period was assessed as extubation (this period was from the discontinuation of anesthetic agents and extubation in minutes) and time to standing (this period was from the discontinuation of anesthetic agents and complete recovery, with the animal returning to standing). Recovery quality was scored from 1 (very good) to 5 (very poor) according to the following scale: score $1=$ sheep standing at first attempt in $<20$ minutes with minimal tremors and no salivation; score 2 = sheep standing at first attempt in $<20$ minutes with moderate tremors and mild salivation; score 3 = sheep standing after more than two attempts, showing marked tremors, bruxism and extensive salivation or lasting more than 30 minutes; score $4=$ sheep standing with marked tremors, bruxism, extensive salivation and mild injuries; and score $5=$ sheep standing with considerable tremors, bruxism and extensive salivation with major complications (excitation, neurotrauma, muscle trauma).

\section{Experimental design}

Food was withheld for 24 hours, and water was withheld for 12 hours. The animals were randomly assigned to one of two groups of six animals, GPF and GPFL. The animals from both groups received premedication with xylazine at a dose of $0.05 \mathrm{mg} /$ $\mathrm{kg}$ intramuscularly (Rompum 2\% - Bayer, São Paulo, SP). After 5 minutes, intravenous catheters were placed in the cephalic vein, and the animals received lactated Ringer's solution at $10 \mathrm{~mL} / \mathrm{kg} / \mathrm{h}$ throughout the procedure. A cuffed esophageal tube was placed to prevent reflux and/or aspiration.
In the GPF group, anesthesia was induced with propofol (Propovan $10 \mathrm{mg} / \mathrm{mL}$, Cristália, São Paulo, $\mathrm{SP}$ ) at a dose of $3 \mathrm{mg} / \mathrm{kg}$ and fentanyl (Fentanest 0,05 $\mathrm{mg} / \mathrm{mL}$, Cristália, São Paulo, SP) at a dose of 2.5 $\mu \mathrm{g} / \mathrm{kg}$ administered over 60 seconds intravenously; after appropriate mandibular relaxation, the trachea was intubated with a Magill endotracheal tube with the aid of a laryngoscope. The left cephalic vein was catheterized and attached to the three-way extensor to which two infusion pumps were connected (Samtronic ST 680, Samtronic, São Paulo, SP), at which time the infusion of propofol $(500 \mu \mathrm{g} / \mathrm{kg} / \mathrm{min})$ and fentanyl began $(0.15 \mu \mathrm{g} / \mathrm{kg} / \mathrm{min})$. Nociceptive stimulation was started after 20 minutes of a CRI. In the GPFL group, the anesthetic induction consisted of an intravaneous bolus of propofol $(3 \mathrm{mg} / \mathrm{kg})$, fentanyl $(2.5 \mu \mathrm{g} / \mathrm{kg}$ ) and lidocaine (Xylestesin $2 \%$, Cristália, São Paulo, SP) $(2.5 \mathrm{mg} / \mathrm{kg})$ before intubation. The three constant rate infusion pumps included propofol $(500 \mu \mathrm{g} / \mathrm{kg} / \mathrm{min})$, fentanyl $(0.15$ $\mu \mathrm{g} / \mathrm{kg} / \mathrm{min})$ and lidocaine $(200 \mu \mathrm{g} / \mathrm{kg} / \mathrm{min})$. After 10 minutes, the propofol dose was reduced by $25 \%$ (from $500 \mu \mathrm{g} / \mathrm{kg} / \mathrm{min}$ to $375 \mu \mathrm{g} / \mathrm{kg} / \mathrm{min}$ ), and anesthesia was maintained for another 10 minutes before nociceptive stimulation began.

Nociceptive stimulation consisted of a surgical procedure, i.e., ventral midline laparotomy. Animals that showed an increase in HR of at least $20 \%$, an increase in MAP or any other signs of pain received an increase in the fentanyl infusion of $50 \%$. When respiratory depression was detected, the animals were mechanically ventilated with a tidal volume of $10 \mathrm{~mL} / \mathrm{kg}$ of $100 \%$ oxygen, and end-tidal carbon dioxide was maintained between 35 to $45 \mathrm{mmHg}$, which was controlled by adjusting the respiratory rate.

Parameters were recorded from 15 minutes after preanesthetic medication administration (T0) to the end of the anesthetic procedure (T7). The time points were as follows: T0 - 15 minutes after preanesthetic medication administration; $\mathrm{T} 1$ - after anesthesia induction and orotracheal intubation; T2 - at 15 minutes of anesthesia; T3 - during traction 
on the liver; T4 - during bowel clamping; T5 during muscle suture; T6 - at the end of skin suture and T7 - 15 minutes after the end of anesthesia.

Postoperative analgesia was provided with an anti-inflammatory treatment (ketoprofen at $3 \mathrm{mg} /$ $\mathrm{kg}$, intravenously) given at time $\mathrm{T} 6$, and analgesic rescue tramadol (2 $\mathrm{mg} / \mathrm{kg}$, intravenously) was used as soon as the animals were standing.

\section{Statistical analysis}

Statistical analysis was performed using software GraphPad Prism, version 5 (GraphPad Software Inc, La Jolla, CA, USA). Comparison of variables within groups was performed using analysis of variance (ANOVA) repeat measures, followed by Bonferroni test. A T-test was used for comparison of variables between groups. Kruskall-Walis test used to compared the quality of recovery. A p $<0.05$ was considered significant.

\section{Results}

The treatment with xylazine promoted weak sedation, requiring complementary physical restraint to perform clipping and install the venous access. The induction of anesthesia was considered good; all animals exhibited no laryngeal reflex and showed muscle relaxation suitable for intubation. Apnea was present in all animals and required mechanical ventilation. The data from respiratory variables are presented in Table 1 . The time, in minutes, between $\mathrm{T} 1$ and $\mathrm{T} 7$ was $110.5 \pm 18.5$ minutes in the GPF group and $116.2 \pm 12.8$ minutes in the GPFL group.

All animals displayed an appropriate level of anesthesia; however, one animal from the GPF group showed mild skin tremors during incision, and two from the GPFL group exhibited thoracic movements and needed an increase in fentanyl to $0.225 \mu \mathrm{g} / \mathrm{kg} /$ minute. Nystagmus was observed in five animals from the GPF group and in four from the GPFL group.

There were no significant differences in blood gas values or end-tidal carbon dioxide between times and treatments $(\mathrm{p}>0.05)$.

The values of HR and MAP were not statistically different over time when compared to the baseline value ( $>0.05$ ) (Figure 1), and the MAP values were lower in the GPF group compared to the GPFL group only at time $\mathrm{T} 6$.

The rectal temperature in the GPF group was significantly lower at times T5, T6 and T7 when compared to the baseline value $(\mathrm{p}>0.05)$. Similarly, in the GPFL group the values were lower at times between T1 and T7 ( $>0.01)$. When comparing the groups, the rectal temperature was lower at $\mathrm{T} 2$ and $\mathrm{T} 3$ in the GPF group versus in the GPFL group $(\mathrm{p}=0.009$ and 0.038 , respectively). 
Table 1. Mean \pm standard deviation of the respiration rate $(f)$, end-tidal carbon dioxide $\left(\mathrm{ETCO}_{2}\right)$, arterial oxygen saturation $\left(\mathrm{SpO}_{2}\right)$, hydrogenionic potential in arterial blood $(\mathrm{pH})$, partial pressure of carbon dioxide $\left(\mathrm{PaCO}_{2}\right)$, partial pressure of oxygen $\left(\mathrm{PaO}_{2}\right)$, bicarbonate ion $\left(\mathrm{HCO}_{3}\right)$ and, base excess (EAB) in sheep submitted to constant rate infusion of propofol/fentanil (GPF) or propofol/fentanil/lidocaine (GPFL) in different times of surgery. - unvalued.

\begin{tabular}{cccccccccc}
\hline Variable & Group & $\mathrm{T} 0$ & $\mathrm{~T} 1$ & $\mathrm{~T} 2$ & $\mathrm{~T} 3$ & $\mathrm{~T} 4$ & $\mathrm{~T} 5$ & $\mathrm{~T} 6$ & $\mathrm{~T} 7$ \\
\hline$f$ & $\mathrm{GPF}$ & $21 \pm 2$ & $10 \pm 2$ & $11 \pm 1$ & $10 \pm 1$ & $9 \pm 2$ & $11 \pm 2$ & $11 \pm 2$ & $12 \pm 3$ \\
$(\mathrm{rmm})$ & $\mathrm{GPFL}$ & $22 \pm 7$ & $12 \pm 3$ & $12 \pm 3$ & $12 \pm 3$ & $11 \pm 3$ & $12 \pm 3$ & $12 \pm 3$ & $11 \pm 3$ \\
$\mathrm{ETCO}_{2}$ & $\mathrm{GPF}$ & - & $38 \pm 6$ & $38 \pm 6$ & $37 \pm 8$ & $37 \pm 6$ & $38 \pm 7$ & $37 \pm 7$ & $41 \pm 10$ \\
$(\mathrm{mmHg})$ & $\mathrm{GPFL}$ & - & $40 \pm 11$ & $41 \pm 10$ & $40 \pm 10$ & $39 \pm 11$ & $39 \pm 11$ & $39 \pm 11$ & $42 \pm 12$ \\
$\mathrm{SpO}_{2}$ & $\mathrm{GPF}$ & - & $98 \pm 0$ & $98 \pm 1$ & $99 \pm 1$ & $98 \pm 2$ & $98 \pm 2$ & $97 \pm 3$ & $98 \pm 1$ \\
$(\%)$ & $\mathrm{GPFL}$ & - & $99 \pm 1$ & $97 \pm 1$ & $98 \pm 2$ & $98 \pm 1$ & $97 \pm 1$ & $97 \pm 2$ & $97 \pm 1$ \\
& $\mathrm{GPF}$ & - & $7.52 \pm 0.1$ & $7.55 \pm 0.1$ & $7.56 \pm 0.1$ & $7.52 \pm 0.1$ & $7.49 \pm 0.1$ & $7.49 \pm 0.1$ & $7.47 \pm 0.1$ \\
$\mathrm{pH}$ & $\mathrm{GPFL}$ & - & $7.47 \pm 0.1$ & $7.46 \pm 0.1$ & $7.47 \pm 0.1$ & $7.46 \pm 0.1$ & $7.42 \pm 0.1$ & $7.42 \pm 0.1$ & $7.40 \pm 0.1$ \\
$\mathrm{PaCO}_{2}$ & $\mathrm{GPF}$ & - & $33 \pm 8$ & $31 \pm 4$ & $30 \pm 5$ & $34 \pm 8$ & $38 \pm 8$ & $38 \pm 9$ & $39 \pm 12$ \\
$(\mathrm{mmHg})$ & $\mathrm{GPFL}$ & - & $40 \pm 8$ & $42 \pm 8$ & $40 \pm 5$ & $41 \pm 8$ & $44 \pm 8$ & $45 \pm 6$ & $49 \pm 3$ \\
$\mathrm{PaO}_{2}$ & $\mathrm{GPF}$ & - & $336 \pm 63$ & $326 \pm 50$ & $314 \pm 50$ & $314 \pm 24$ & $310 \pm 62$ & $341 \pm 37$ & $333 \pm 44$ \\
$(\mathrm{mmHg})$ & GPFL & - & $353 \pm 34$ & $335 \pm 27$ & $335 \pm 19$ & $315 \pm 14$ & $320 \pm 34$ & $326 \pm 33$ & $323 \pm 52$ \\
$\mathrm{HCO}_{3}$ & GPF & - & $27 \pm 4$ & $27 \pm 3$ & $27 \pm 3$ & $27 \pm 4$ & $29 \pm 3$ & $31 \pm 5$ & $30 \pm 6$ \\
$(\mathrm{mmol} / \mathrm{L})$ & GPFL & - & $28 \pm 1$ & $29 \pm 1$ & $29 \pm 1$ & $29 \pm 2$ & $28 \pm 3$ & $29 \pm 2$ & $31 \pm 2$ \\
$\mathrm{ABE}$ & GPF & - & $5 \pm 5$ & $5 \pm 4$ & $5 \pm 4$ & $5 \pm 4$ & $4 \pm 2$ & $4 \pm 3$ & $4 \pm 5$ \\
$(\mathrm{mmol} / \mathrm{L})$ & GPFL & - & $4 \pm 1$ & $5 \pm 2$ & $5 \pm 2$ & $4 \pm 1$ & $5 \pm 2$ & $5 \pm 2$ & $5 \pm 2$ \\
\hline
\end{tabular}

Source: Elaboration of the authors. 
Figure 1. Mean \pm standard deviation of the heart rate (HR), median arterial pressure (MAP) and rectal temperature (RT) in sheep submitted to constant rate infusion of propofol/fentanil (GPF) or propofol/fentanil/lidocaine (GPFL) in different times of surgery. Difference between groups at this time $(\mathrm{p}<0.05)$.
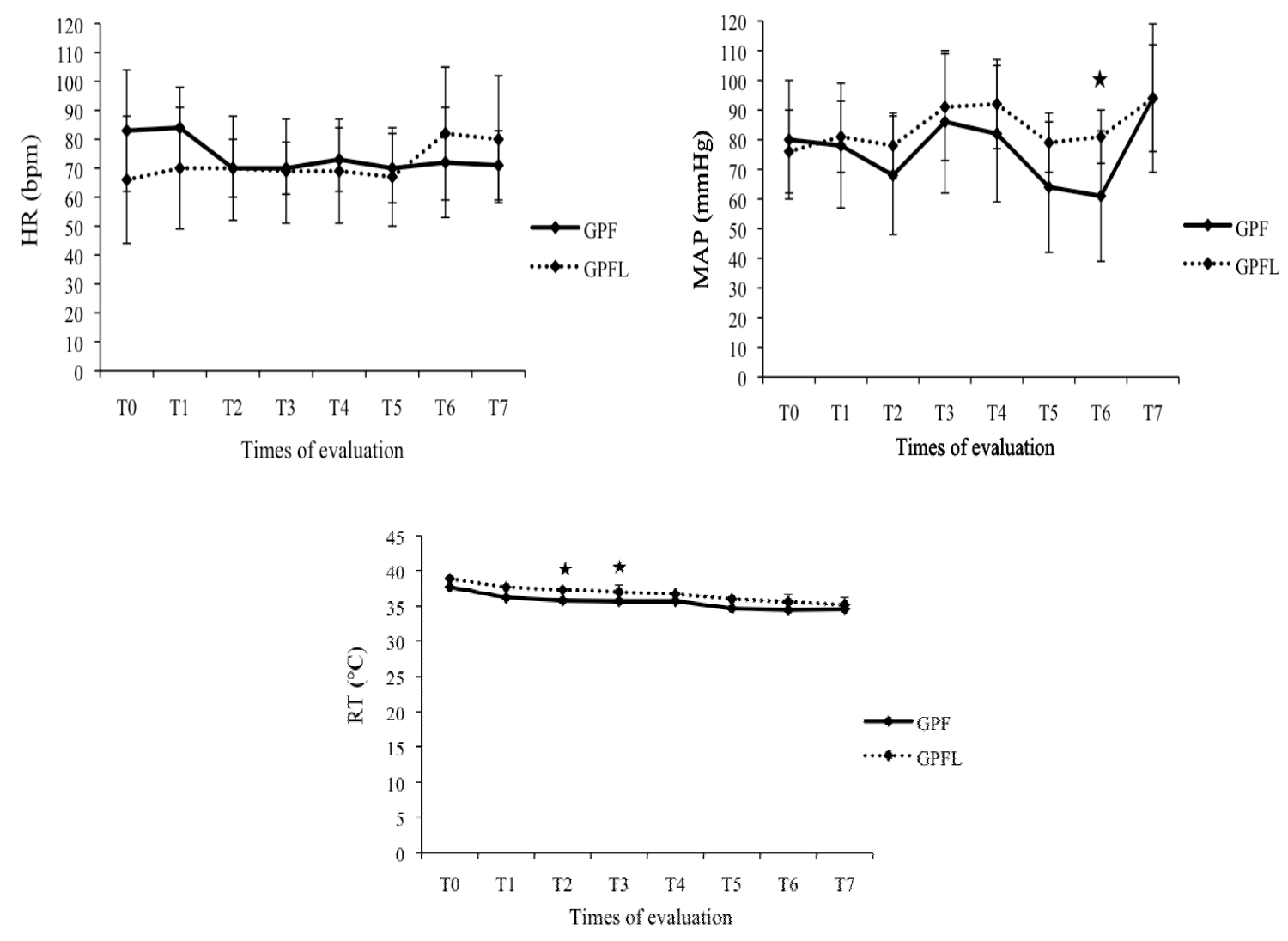

Source: Elaboration of the authors.

For the time to extubation, in minutes, was 9.3 \pm 5.5 for the GPF group and $11.3 \pm 3.4$ minutes for the GPFL group, with no difference observed $(p=0.985)$. Additionally, there was no difference in the time to standing position $(\mathrm{p}>0,05)$, with mean times of $128.8 \pm 7.7$ and $132.3 \pm 9.8$ minutes for the GFP and GPFL groups, respectively. The quality recovery scores were similar between groups ( $\mathrm{p}=0.864)$, and the median (25th to 75 th percentile range) was 3.0 (2.5-3.8) in the GPF group and 3.1 (3.0-4.1) in the GPFL group.

\section{Discussion}

The dose for inducing anesthesia was based on the study by Handel et al. (1991), which used 6 mg/ $\mathrm{kg}$ in sheep, a higher dose than that observed in dogs (NOLAN; REID, 1993) and horses (NOLAN; HALL, 1985) and similar to that used in cats (BREARLEY; KELLAGHER; HALL, 1988).

Correia, Nolan and Reid (1996) used propofol in sheep at a dose of $4 \mathrm{mg} / \mathrm{kg}$ or $3 \mathrm{mg} / \mathrm{kg}$ combined with $1 \mathrm{mg} / \mathrm{kg}$ of ketamine and observed that no change was detected in either group; thus, these are the appropriate doses for intubation. Covey-Crump and Murison (2008) noted an improvement in the quality of induction when they used fentanyl combined with propofol for anesthetic induction in dogs. Rawlings and Kolata (1983) observed that lidocaine administered concomitantly with thiopental also improved the induction quality in dogs. 
The occurrence of apnea after propofol induction is common. This phenomenon is attributed to its direct effects on the respiratory center (SEBEL, LONDOW, 1989), and/or the passage of the endotracheal tube (MURRISON, 2001). Moreover, this effect may be enhanced by the combination with fentanyl, because this drug can cause significant respiratory depression during anesthesia (HALL; CLARK; TRIM, 2001). Morgan and Legge (1989) noted that apnea was the most common side effect observed in dogs when using propofol. Similarly, Murrison (2001) observed a 64\% occurrence of apnea in dogs that received propofol. In the same species, Covey-Crump and Murison (2008) observed respiratory depression when animals were induced to anesthesia with a combination of propofol $(4 \mathrm{mg} / \mathrm{kg})$ and fentanyl $(2 \mu \mathrm{g} / \mathrm{kg})$. Handel et al. (1991) observed that administering propofol in sheep at a dose of $5 \mathrm{mg} / \mathrm{kg}$ promoted apnea lasting for 3-4 seconds after intubation, but after this period the animals returned to spontaneous breathing. Correia, Nolan and Reid (1996) did not report the occurrence of apnea with $4 \mathrm{mg} / \mathrm{kg}$ in the same species. However, they did note a respiratory rate reduction during maintenance in the group receiving propofol alone when compared to those maintained with propofol/ketamine.

The time allotted for mechanical ventilation was relatively short (ten seconds), but it would have been risky to observe the possibility of returning to spontaneous breathing because the animals were already cyanotic. The apnea in ruminants may be related to rumen distension due to the production of gas by the microbial flora (UNREGER et al., 1976). Moreover, the lateral decubitus position may swell and produce respiratory depression (FUJIMOTO; LENEHAN, 1985).

The anesthetic maintenance with a propofol dose of $500 \mu \mathrm{g} / \mathrm{kg} /$ minute was similar to the study reported by Correia, Nolan and Reid (1996) when they used sheep for implanting a device in the subcutaneous tissue. Based on the classic signs of anesthetic depth proposed by Guedell (1937), among which are the heart rate and blood pressure, this dose combined with other drugs was sufficient for the animals to remain at an appropriate anesthesia level. Eyelid reflex or the occurrence of tremors are not always associated with pain.

Moreover, shivering is common in anesthesia with propofol; spontaneous muscle movement by opioids and the occurrence of nystagmus is a common sign in ruminants and should not always be interpreted as a superficial level of anesthesia (HASKINS, 2007). Some of these signs may be observed without them actually interfering with the cardiovascular parameters.

Propofol has a good hypnotic action; however, its analgesic effects are virtually nonexistent, and its isolated use as a maintenance anesthetic in invasive procedures is inappropriate (DUKE, 1995). Hence, its combination with potent opioids is an option. The effects of opioids in ruminants are controversial (DOHERTY et al., 2004). Waterman, Livingston and Amin (1990) showed that doses of $5 \mu \mathrm{g} / \mathrm{kg}$ of fentanyl administered as a bolus in sheep did not show any antinociceptive effect against mechanical stimulation. However, when the dose was increased to 10 and $20 \mu \mathrm{g} / \mathrm{kg}$ it proved to be effective. Nolan, Livingston and Waterman (1987), in a study with sheep, compared xylazine and clonidine with meperidine and buprenorphine for mechanical stimulation and observed that the alpha $_{2}$-agonists showed better analgesic effects. Doherty et al. (2004) assessed the reduction of the minimum alveolar concentration of isoflurane in goats by the administration of $2 \mathrm{mg} / \mathrm{kg}$ of morphine and reported a reduction of $29.7 \%$. This value was considered low when compared to the reduction levels achieved with the same protocols in dogs.

The combination of propofol and fentanyl enabled satisfactory surgical conditions, and although its influence on the reduction rate of propofol was not the objective of the study, clinical observations during the procedure suggested that the inclusion of an opioid did not allow for significant reductions. 
The exact mechanism by which lidocaine promotes a reduction in the anesthetic requirement is still uncertain. However, it is supposedly due to its sedative or analgesic effect or possibly to a combination of both (DOHERTY et al., 2007). Doherty et al. (2007), in a study with goats, evaluated the reduction of the minimum alveolar concentration of isoflurane by the infusion of $100 \mu \mathrm{g} / \mathrm{kg} /$ minute of lidocaine and found a decrease of $18.3 \%$. However, in ponies the reduction can reach up to $70 \%$ of halothane on MAC (DOHERTY; FRAZIER, 1998). Senturky et al. (2002) observed that a single dose of lidocaine by intramuscular injection in humans was sufficient to reduce the necessary dose of propofol to maintain anesthesia by $29 \%$. Mannarino (2002) found that applying $2.5 \mathrm{mg} / \mathrm{kg}$ followed by the infusion of $250 \mu \mathrm{g} / \mathrm{kg} /$ minute resulted in a reduction of $21 \%$ in the required propofol dose in dogs.

The literature data regarding the influence of lidocaine are scarce and inconsistent, and there is variation between the anesthetic drug used and the species. The study herein demonstrated that the dose of lidocaine used was sufficient to reduce the maintenance dose of propofol by $25 \%$. Both protocols promoted stability from a cardiovascular point of view and are also appropriate to prevent the response of the system during stimulation.

Hypothermia in dogs is defined as a temperature below $37{ }^{\circ} \mathrm{C}$ (ONCKEN; KIRBY; RUDLOFF, 2001). The same criterion can be used in sheep due to the similarity of their physiological temperature patterns. Studies in human patients have demonstrated that moderate hypothermia in the perioperative period is responsible for a number of disorders, among which are tachycardia, hypertension, systemic vasoconstriction, dysfunction in the balance between oxygen supply and demand in the myocardium and increased levels of circulating catecholamines (FRANK et al., 1995). These effects are in addition to interfering with the anesthetic recovery (POTTIE et al., 2007), which would be detrimental to ruminants because of regurgitation. In addition to the changes directly related to the anesthetic drugs, other factors may influence body temperature during the procedure, for instance, exposure of the abdominal content, contact with the surgical table, reduced temperatures in the operating room and the administration of unheated parenteral solutions (PUTZU et al., 2007). The lower rectal temperature values of the GPF group suggest that these results were due to the higher amount of propofol administered. This is based on the presupposition that this drug is responsible for dose-dependent peripheral vasodilation (NOLAN; REID, 1993), and therefore, more pronounced heat loss.

The inclusion of lidocaine did not influence the recovery period, but in both groups the times to extubation and to remain in a quadrupedal position were higher than those reported by Correa, Nolan and Reid (1996), who observed 2.8 and 6.3 minutes, respectively, in sheep subjected to anesthesia with propofol at a dose of $0.5 \mathrm{mg} / \mathrm{kg} /$ minute isolatedly. Based on this, it seems that the combination of fentanyl and lidocaine may have prolonged the recovery time. Hughes and Nolan (1999) reported that for dogs anesthetized with propofol combined with fentanyl, the extubation time and the time to resume quadrupedal position were 21 and 95 minutes, respectively. For the same species, Mannarino (2002) observed that the inclusion of $250 \mu \mathrm{g} / \mathrm{kg} /$ minute of lidocaine in the protocol with propofol at a dose of $985 \mu \mathrm{g} / \mathrm{kg} /$ minute increased the extubation time from 35 to 44 minutes and the time to quadrupedal position from 148 to 157 minutes.

The quality of recovery is extremely important, and excitatory phenomena are undesirable. At this time, excitement may be related to pain (TAYLOR, 1990), although ketoprofen had been administered. Our results may have been influenced by the presence of pain, given that the analgesic rescue was performed after the animal was in quadrupedal position. An intraoperative CRI of lidocaine (50 $\mu \mathrm{g} / \mathrm{kg} /$ minute) induces ataxia and a poor quality of recovery in horses; thus, it is necessary to discontinue the infusion 30 minutes before the end of surgery 
(VALVERDE et al., 2005). In horses, Valverde et al. (2010) reported that the combination of a CRI of lidocaine and medetomidine induces better recovery quality scores. However, the time for the animals to remain standing was longer compared with lidocaine alone, whereas this authors assign this improved effect to the sedative effects of medetomidine. When fentanyl is used in sheep at a dose of $10 \mu \mathrm{g} /$ $\mathrm{kg}$ i.v., sedation continues for 60 minutes after its administration (WATERMAN; LIVINGSTON; AMIN, 1990), although one case of prolonged recovery has also been reported (KRONEN et al., 2005). Analyzing the results of these authors, it is possible that the residual sedative and analgesic effects of fentanyl (HUGHES; NOLAN, 1999) may have influenced the scores observed in the GPFL group because no signs of excitation were observed.

\section{Conclusions}

A high-dose CRI ( $200 \mu \mathrm{g} / \mathrm{kg} /$ minute $)$ of lidocaine in combination with a propofol/fentanyl regimen did not promote significant cardiovascular changes and was effective in reducing the propofol dose by $25 \%$ to maintain anesthesia. In both combinations, a reduction of the rectal temperature as well as respiratory depression requiring mechanical ventilation occurs.

\section{References}

BRANSON, K. R. Injectable and alternative anesthetic techniques. In: TRANQUILLI, W. J.; THURMON, J. C.; GRIMM, K. A. (Ed.). Lumb \& jones' veterinary anesthesia and analgesia. $4^{\text {th }}$ ed. Blackwell Publishing: Iowa, 2007. p. 273-300.

BREARLEY, J. C.; KELLAGHER, R. E. B.; HALL, L. W. Propofol anaesthesia in cats. Veterinary Anaesthesia Analgesia, Malden, v. 15, n. 1, p.142, 1988.

CORREIA, D.; NOLAN, A. M.; REID, J. Pharmacokinetics of propofol infusions, either alone or with ketamine, in sheep premedicated with acepromazine and papaveretum. Research Veteterinary Science, Maryland Heights, v. 60, n. 3, p. 213-217, 1996.
COVEY-CRUMP, G. L.; MURRISON, P. J. Fentanyl or midazolam for co-induction of anaesthesia with propofol in dogs. Veterinary Anaesthesia Analgesia, Malden, v. 35, n. 6, p. 463-472, 2008.

DOHERTY, T. J.; FRAZIER, D. L. Effect of intravenous lidocaine on halothane minimum alveolar concentration in ponies. Equine Veterinary Journal, Cambridgeshire, v. 30, n. 4, p. 300-303, 1998.

DOHERTY, T. J.; REDUA, M. A.; QUEIROZ-CASTRO, P.; EGGER, C.; COX, S. K.; ROHRBACK, R. H. Effect of intravenous lidocaine and ketamine on the minimum alveolar concentration of isoflurane in goats. Veterinary Anaesthesia Analgesia, Malden, v. 34, n. 2, p. 125-131, 2007.

DOHERTY, T. J.; WILL, W. A.; ROHRBACH, B. W.; GEISER, D. R. Effect of morphine and flunixim meglumine on isoflurane minimum alveolar concentration in goats. Veterinary Anaesthesia Analgesia, Malden, v. 31, n. 2, p. 97-101, 2004.

DUKE, T. A new intravenous anesthetic agent: propofol. Canadian Veterinary Journal, Ottawa, v. 36, n. 3, p. 181183, 1995.

ENDERLE, A. K.; LEVIONNOIS, O. L.; KUHN, M.; SCHATZMANN, U. Clinical evaluation of ketamine and lidocaine intravenous infusions to reduce isoflurane requirements in horses under general anaesthesia. Veterinary Anaesthesia Analgesia, Malden, v. 35, n. 4, p. 297-305, 2008.

FRANK, S. M.; HIGGINS, M. S.; BRESLOW, M. J.; FLEISHER, L. A.; GORMAN, R. B.; SITZMANN, J. V.; RAFF, H.; BEATTIE, C. The cathecolamine, cortisol, and hemodynamic responses to mild perioperative hypothermia. A randomized clinical trial. Anesthesiology, Danvers, v. 82, n. 1, p. 83-93, 1995.

FUJIMOTO, J. L.; LENEHAN, T. M. The influence of body position on the blood gas and acid-base status of halothane-anesthetized sheep. Veterinary Surgery, Malden, v. 14, n. 2, 169-172, 1985.

GUEDEL, A. E. Inalation anesthesia: a fundamental guide. Macmillian: New York, 1937. p. 25-28.

HALL, L. W.; CLARKE, K. W.; TRIM, C. M. Anesthesia of sheep, goats and other herbivores. In: HALL, L. W.; CLARKE, K. W.; TRIM, C. M. Veterinary anaesthesia. $10^{\text {th }}$. ed. London: W. B. Saunders, 2001. p. 341-365.

HANDEL, I. G.; WEAVER, B. M. Q.; STADDON, G. E.; MADORRAN, C. J. I. Observations on the pharmacokinetics of propofol in sheep. Veterinary Anaesthesia Analgesia, Malden, v. 18, n. 1, p. 143-154, 1991. 
HASKINS, S. C. Monitoring anesthetized patients. In: TRANQUILLI, W. J.; THURMON, J. C.; GRIMM, K. A. (Ed.). Lumb \& jones' veterinary anesthesia and analgesia. $4^{\text {th }}$ ed. Blackwell Publishing: Iowa, 2007. p. 533-558.

HUGHES, J. M.; NOLAN, A. M. Total intravenous anesthesia in greyhounds: pharmacokinetics of propofol and fentanyl--a preliminary study. Veterinary Surgery, Malden, v. 28, n. 6, p. 513-524, 1999.

KRONEN, P. W.; LEVIONNOIS, O. L.; ECKSTEIN, F. S.; MOENS, P. S. Prolonged recovery and respiratory depression after fentanyl infusion in a sheep undergoing mitral valve reconstruction. Laboratory Animals, London, v. 39, n. 4, p. 428-434, 2005.

LAMONT, L. A.; MATHEWS, K. A. Opioids, nonsteroidal anti-inflamtories, and analgesic adjuvants. In: TRANQUILLI, W. J.; THURMON, J. C.; GRIMM, K. A. (Ed.). Lumb \& Jones' veterinary anesthesia and analgesia. $4^{\text {th }}$ ed. Blackwell Publishing: Iowa, 2007. p. 241-271.

MANNARINO, R. Determinação da taxa de infusão minima de propofol e propofol associado a lidocaína em cães (Cannis familiaris). 2002. Dissertação (Mestrado em Anestesiologia) - Faculdade de Medicina. Universidade Estadual Paulista Júlio de Mesquita Filho, Botucatu.

MATSUBARA, L. M.; OLIVA, V. N.; GABAS, D. T.; OLIVEIRA, G. C.; CASSETARI, M. L. Effect of lidocaine on the minimum alveolar concentration of sevoflurane in dogs. Veterinary Anaesthesia Analgesia, Malden, v. 36, n. 5, p. 407-413, 2009.

MORGAN, D. W. T.; LEGGE, K. Clinical evaluation of propofol as an intravenous anaesthetic agent in cats and dogs. Veterinary Record, London, v. 124, n. 2, p. 31-33, 1989 .

MURRISON, P. J. Effect of propofol at two injection rates or thiopentone on post-intubation apnoea in the dog. Journal Small Animal Practice, Hoboken, v. 42, n. 2, p. 71-74, 2001.

NOLAN, A. M.; HALL, L. W. Total intravenous anesthesia in the horse with propofol. Equine Veterinary Journal, Cambridgeshire, v. 70, n. 5, p. 546-551, 1985.

NOLAN, A.; LIVINGSTON, A.; WATERMAN, A. Antinociceptive actions of intravenous alpha 2-adrenoreceptor agonists in sheep. Journal Veterinary Pharmacology Therapeutics, Hoboken, v. 10, n. 3, p. 202-209, 1987.

NOLAN, A.; REID, J. Pharmacokinetics of propofol administered by infusion in dogs undergoing surgery. British Journal Anaesthesia, Oxford, v. 70, n. 5, p. 546551, 1993.
ONCKEN, A. K.; KIRBY, R.; RUDLOFF, E. Hypothermia in critically ill dos and cats. Compendium Continuation Education Veterinary, Wisconsin, v. 23, n. 6, p. 506-521, 2001.

POTTIE, R. G.; DART, C. M.; PERKINS, N. R.; HODGSON, D. R. Effect of hypothermia on recovery from general anesthesia in the dog. Australian Veterinary Journal, Hoboken, v. 85, n. 4, p. 158-162, 2007.

PUTZU, M.; CASATI, A.; BERTI M.; POGLIARINI, G.; FANELLI, G. Clinical complications, monitoring and management of perioperative mild hypothermia: anesthesiological features. Acta Biomedica, Parma, v. 78, n. 3, p. 163-169, 2007.

PYPENDOP, B. H.; ILKIW, J. E. The effects of intravenous lidocaine administration on the minimal alveolar concentration of isoflurane in cats. Anesthesia Analgesia, Baltimore, v. 100, n. 1, p. 97-101, 2005.

RAWLINGS, C. A.; KOLATA, R. J. Cardiopulmonary effects of thiopental/lidocaine combination during anesthetic induction in the dog. American Journal Veterinary Research, Schaumburg, v. 44, n. 1, p. 144149, 1983.

SEBEL, P. S.; LOWDON, J. D. Propofol: a new intravenous anesthetic. Anesthesiology, Danvers, v. 71, n. 2, p. 260-277, 1989.

SENTURKY, M.; PEMBECI, K.; MENDA, F.; OZKAN, T.; GUCYETMEZ, B.; TUGRUL, M.; CAMCI, E.; AKPIR, K. Effects of intramuscular administration of lidocaine or bupivacaine on induction or maintenance doses of propofol evaluated of bispectral index. British Journal Anaesthesia, Oxford, v. 89, n. 6, p. 849-852, 2002.

TAYLOR, P. M. Anaesthesia in sheep and goats. In Practice, Cambridge, v. 17, n. 1, p. 32-34, 1990.

UNREGER, T.; ORR, J. A.; BISGARD, G. E.; WILL, J. A. Cardiopulmonary effects of mechanical distension of the rumen in nonanesthetized sheep. American Journal Veterinary Research, Schaumburg, v. 37, n. 7, p. 807810, 1976.

VALVERDE, A.; DOHERTY, T. J.; HÉRNANDEZ J.; DAVIES, W. Effect of lidocaine on the minimum alveolar concentration of isoflurane in dogs. Veterinary Anaesthesia Analgesia, Malden, v. 31, n. 4, p. 264-271, 2004.

VALVERDE, A.; GUNKELT, C.; DOHERTY, T. J.; GIGUĖRE, S.; POLLAK, A. A. Effect a constant rate infusion of lidocaine on the quality of recovery from sevoflurane or isoflurane general anesthesia in horses. Equine Veterinary Journal, Cambridgeshire, v. 37, n. 6, p. 559-564, 2005. 
VALVERDE, A.; RICKEY, E.; SINCLAIR, M.; RIOJA, E.; PEDERNERA, J.; HATHWAY, A.; CRUZ, A. Comparison of cardiovascular function and quality of recovery in isoflurane-anaesthetised horses administered a constant rate infusion of lidocaine or lidocaine and medetomidine during elective surgery. Equine Veterinary Journal, Cambridgeshire, v. 42, n. 3, p. 192-199, 2010.

WATERMAN, A. E.; LIVINGSTON, A.; AMIN, A. The antinociceptive activity and respiratory effects of fentanyl in sheep. Veterinary Anaesthesia Analgesia, Malden, v. 17, n. 1, p. 20-23, 1990. 